\title{
Laparoscopy and Well-Differentiated Papillary Mesothelioma of the Peritoneum
}

\author{
María Eugenia Aponte-Rueda, Ramón Saade-Cárdenas and \\ Salvador Navarrete-Aulestia \\ Endoscopic Surgery Unit, Service of Surgery 2, Caracas University Hospital, \\ Central University of Venezuela \\ Venezuela
}

\section{Introduction}

Mesothelioma, is a rare and poorly understood disease that arises from mesothelial cells lining serous cavities. From a histopathologic point of view there are epithelial, connective tissue and mixed varieties. Although commonly found in the pleura, the peritoneum is involved in $20-40 \%$ of cases. ${ }^{1-5}$

Well-Differentiated Papillary Mesothelioma of the Peritoneum (WDPMP) is a type of epithelial mesothelioma which typically shows benign biological behavior, ${ }^{6-12}$ although several cases with a more aggressive form have been reported. ${ }^{13-18}$ Being uncommon, it lacks of specific clinical and radiological manifestations, ${ }^{19-21}$ and it is difficult to obtain precise information regarding its natural history and optimal management. The diagnosis is challenging and the delay is a component of the clinical picture of these patients. This chapter evaluates the applicability of laparoscopy when this entity is suspected.

\section{Diagnosis}

There is nonspecific presentation for peritoneal mesothelioma and the clinical diagnosis is difficult. Symptomatology is insidious, undefined and unspecific, but it can appear as a surgical emergency, ${ }^{22-23}$ although usually the disease is diagnosed incidentally during a laparoscopy, done for another other reason. Generally, the patient with peritoneal mesothelioma shows up with one or two types of symptoms and signs: those with abdominal pain, usually localized and related to an abdominal mass with little or no ascites and those, without abdominal pain, but with ascites and distension. ${ }^{24} \mathrm{~A}$ history of asbestos exposure is common in patients with pleural mesothelioma, but this association has not been firmly established in the case of the peritoneal mesothelioma. ${ }^{25}$

One of the clinical poorly understood aspects of this disease is the low diagnostic yield of the cytologic analysis of ascites. In a study of 51 patients with peritoneal mesothelioma, Sugarbaker et $\mathrm{al}^{26}$ found that only two patients had a definitive diagnosis established by paracentesis of the intrabdominal fluid and the cytology. The analysis of the ascitic fluid usually reveals an exudative process, varying from clearly, mucinosous or serohematic. The cytology can be diagnostic in approximately $80 \%$ of cases with an adequate sample, but it has to be related to an abdominal mass. ${ }^{27}$ In some cases it has been reported to be useful for 
the diagnosis of Well-Differentiated Papillary Mesothelioma.28-29 No tumor marker is reliable for diagnosis.

Peritoneal Mesothelioma does not have specific radiological characteristics. Therefore, a precise diagnosis based on imaging findings alone is not possible; in addition, distinguishing between benign and malignant processes, as well as primary and metastatic processes is also difficult (Figure 1). Lovell et al ${ }^{19}$ found that the Computed Tomography Scan is clearly superior to the ultrasound, specifically detecting small tumoral nodules and mesenteric or peritoneal thickening. The Tomography can reveal a peritoneal enhancing soft-tissue mass within the mesentery, omentum or peritoneum thickening, multiple small nodules surrounding the peritoneum, mesentery and omentum. Other findings include ascites, infiltrating mass involving the serous of the bowels, direct invasion within the liver, spleen and abdominal wall, retroperitoneal adenopathies and metastasis at distance. ${ }^{30}$ The pelvic involvement can suitably be evaluated by ultrasound as well as a small amount of liquid at cul-de-sac. ${ }^{19} \mathrm{Few}$ data has been published about the magnetic resonance imaging and PET-CT imaging manifestations. Due to no specificity in clinical characteristics and the low trust of the conventional techniques in the diagnosis of mesothelioma, the laparoscopic surgery will allow assuring the definitive diagnosis and nowadays it is preferable to laparotomy, due to lower invasiveness. Application of diagnostic laparoscopy allows direct visualization of the abdominal-pelvic peritoneum and organs, and may disclose laparoscopic characteristics, which beside the direct vision biopsy allows the diagnostic accuracy of this uncommon medical entity.
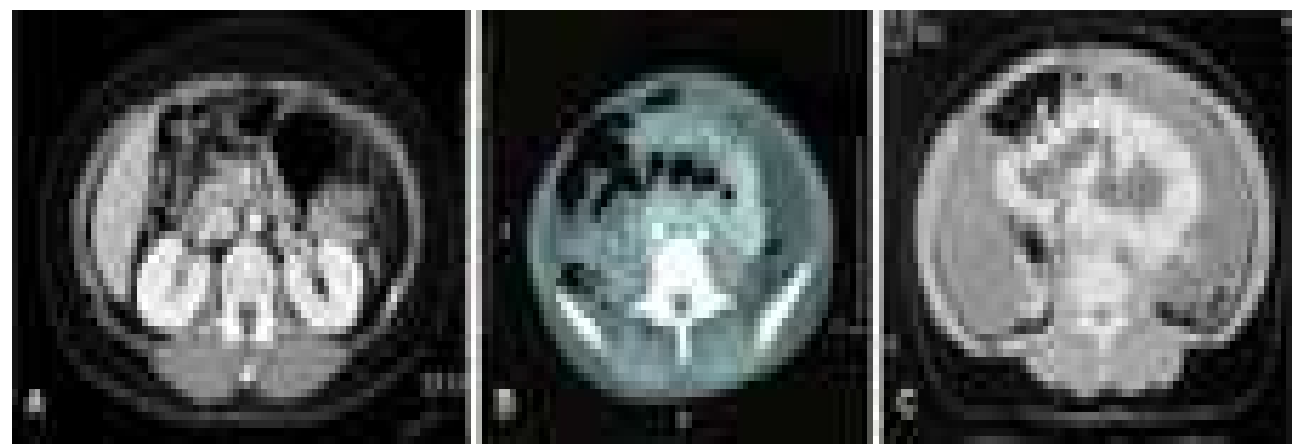

Fig. 1. Axial Contrast Abdominal-Pelvic Computer Tomography shows multiple round nodules and mesenteric and peritoneal thickening and ascites. A. WDPM (courtesy of Dr. Hyuong Sun Jang and Ki Young Ru) ,B. Peritoneal Carcinomatosis, C. Peritoneal Tuberculosis (courtesy of Dr Suárez-Grau and Dr Morales-Conde).

\section{Laparoscopic surgery}

The first case of peritoneal mesothelioma, involving the laparoscopic surgery and the peritoneal biopsy, was published in $1974 .{ }^{31}$ Nowadays the diagnostic laparoscopic surgery offers a fast, safe and less invasive form to confirm the diagnosis of peritoneal mesothelioma. We must consider the laparoscopic approach as the main technique for correct visualization of the peritoneal cavity, peritoneal fluid and multiple peritoneal biopsies obtained from intra-abdominal locations, to diagnose a multitude of 
gastrointestinal diseases showing abdominal pain and ascites of unknown etiology. Yoon et $\mathrm{al}^{39}$ reported a diagnostic yield of $87.2 \%$ for diagnostic laparoscopy in patients with ascites of unknown origin. Piccigallo et $\mathrm{al}^{40}$ reported the correct diagnosis using the laparoscopic surgery and the histological examination of biopsy specimens, reaching a percentage of diagnostic security near $90 \%$, in patients diagnosed with Malignant Peritoneal Mesothelioma. In patients with Well Differentiated Papillary Mesothelioma of the Peritoneum the laparoscopic surgery reduces the period of observation and for that reason, the repetition of examinations and other explorations, as well as avoiding the inherent complications related to laparotomy, with a more comfortable post-operative evolution by the smaller surgical trauma. Accurate diagnosis allows a precise therapy to be promptly started. The majority of authors recommend multiple biopsies with or without adjuvant therapy, instead of an extensive surgery due to its low malignant potential. We reported a case of WDPMP showing its resolution after adjuvant chemotherapy. 41

Diagnostic laparoscopic surgery is useful for staging pleural mesothelioma ${ }^{42}$ (although only two cases of Well Differentiated Papillary Mesothelioma, involving the peritoneal and pleural cavities, have been published). ${ }^{16-43}$ In cases of isolated pelvic nodules it can provide anatomic information, allows definitive management and pathologic diagnosis, therefore, to diagnose and treat WDPMP the laparoscopic approach can be used effectively and safely. ${ }^{21,44}$

\subsection{Surgical technique}

The diagnostic laparoscopic surgery can be done under general anesthesia or under local anesthesia and sedation. The table essentially will be moved into: steep anti-Trendelenburg + left tild, anti-Trendelenburg + right tild, steep Trendelenburg + left tild, steep Trendelenburg + right tild during the examination to mobilize the ascitic fluid and the intestine. The surgeon and assistants are positioned on the patient's left side. The monitor is placed right to the patient's head. The normally used instrument is a rigid endoscope with the optic connected to a cold light source, of $5 \mathrm{~mm}$ with a forward viewing angle of view of $0^{\circ}$ and oblique viewing of $30^{\circ}$. For the exploration of the peritoneal cavity, it is necessary to create a suitable pneumoperitoneum that is induced by $\mathrm{CO}_{2}$ insufflation, an intraabdominal pressure of 10 to 12 $\mathrm{mm}$ is the adopted to secure a good vision. At the same time there it is introduced a supra or transumbical trocar and the laparoscope is passed through it, inspecting the peritoneal cavity. A second and third trocar (10 $\mathrm{mm}$ and $5 \mathrm{~mm}$, respectively) can be positioned under visual control for biopsy and introduction of accessory instruments, according to the particular requirements in each case. In order to avoid complications, it is recommended to follow carefully a entry procedure technique due to adhesions between the small bowel loops and the abdominal wall. We use a blunt tip trocar described by Hasson, 45 to enter the abdominal cavity, a small incision must be done under direct vision and the aponeurotic hole has to be adjusted by stitches to the Hasson trocar to avoid neumoperitoneum leaks.

\subsection{Abdominal cavity exploration}

Begin the exploration with the table in horizontal position. The presence of ascites in abdominal cavity is evaluated and its characteristics. Cytology and bacteriology samples should be taken under direct vision and finally the ascites should be completely emptied. The situation and degree of alterations must be defined.

Then, the laparoscopic exploration must follow a defined systematic plan, covering the different quadrants of the cavity (Figure 2). 


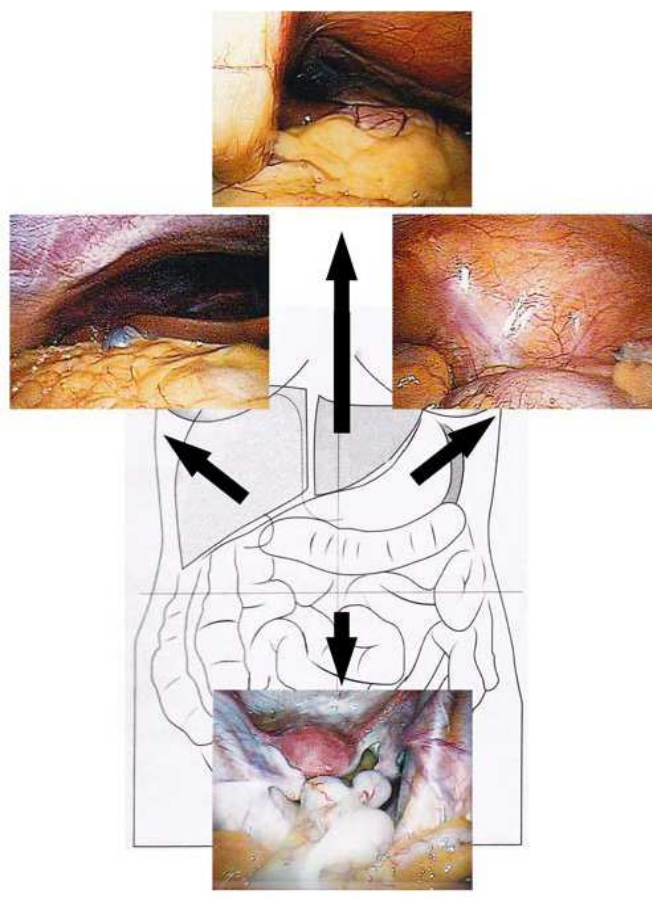

Fig. 2. Laparoscopic Exploration

Henning and Look ${ }^{46}$ described four positions that allow a good vision of the entire peritoneal cavity; such positions can be modified according to the particular requirements of each case. In position I, it turns the table slightly $\left(15-20^{\circ}\right)$ towards the left and raise to the head other $15-20^{\circ}$. Being the explorer to the left of the patient, the laparoscope is introduced towards the right hypochondrium, which allows to observe the gallbladder, the hepatic edge, the surface of the right lobe and right side of the falciform ligament. The rotation of the optics, the variation of the intensity of the position or the cephalic elevation of the table provides a vision of the entire region.

Position II is the same as I, but laparoscope moves under the round ligament, until reaching the left hypochondrium. If the light goes towards the right, the left hepatic lobe could be observed, the left side of the falciform ligament and the diafragm. If it goes towards the left side, it could see the anterior face of the stomach and the epiploic fat.

Position III is achieved changing the position towards the right side $\left(45^{\circ}\right)$ and lifting the head on the exploration table $\left(40^{\circ}\right)$, with the surgeon at the right side. In this case, the spleen, the frenic and colonic ligament, good part of the anterior face of the stomach, including fornix and possibly, also the esofagic hiatus can be seen, if the gastrohepatic ligament allows it.

Position IV is to inspect the inferior quadrants (pelvic region) and the rest of intraabdominal organs. This position requires the Trendelenburg's position, turning the table towards the side that we wish to explore. The changes from one position to another require a lateral displacement of the optic, which always must be done in the sense of the iluminated field, to avoid tears of adhesions. In this case, the monitor should be placed down and to the right side of the patient. 


\subsection{Laparoscopic findings}

WDPMP, due to its rarity the surgeons are usually not sensitive with the disease. Laparoscopic findings of mesothelioma are indistinguishable of peritoneal tuberculosis, metastatic adenocarcinoma or primary tumour of the mesentery, from the gross standpoint, the common presentation sign of peritoneal nodules in WDPMP may lead to confusion during the diagnostic laparoscopic surgery, therefore a diagnosis is frequently difficult. However, the increased use of laparoscopic surgery to identify pathologic causes of ascitis of unknown origin, as well as pelvic pain, particularly in young women, which implies that the surgeons must be conscious of the laparoscopic characteristics of this tumor and distinguished from other common neoplasms involving the peritoneum to be enabled to properly recognize and treat the tumor.

The laparoscopic features of the Peritoneal Mesothelioma, are: 40

a. The presence of homogeneous spreading of nodules, plaques or masses on both parietal and visceral peritoneum (Figure 3). The nodules become more confluent plaque like masses and eventually omental span is observed with the progression of the disease ${ }^{41}$ (Figure 4).

The nodules usually are:

- Heterogenous size: The size of nodules is variable. Most of them appeared to be in the range of $0.5 \mathrm{~cm}$ to $2.0 \mathrm{~cm}$, located in the abdomen and pelvis. ${ }^{18}$ If they appear under the form of a fine dissemination to miliar, therefore they can simulate the typical aspect of the tuberculous elements. ${ }^{47}$ They can one or multiple be distributed by the totality of the peritoneal cavity, omentum and mesentery. Occasionally, small foci of tumor are present in the surface of the ovary ${ }^{18}$ (Figure 5).

- White color.

- Firm consistency.

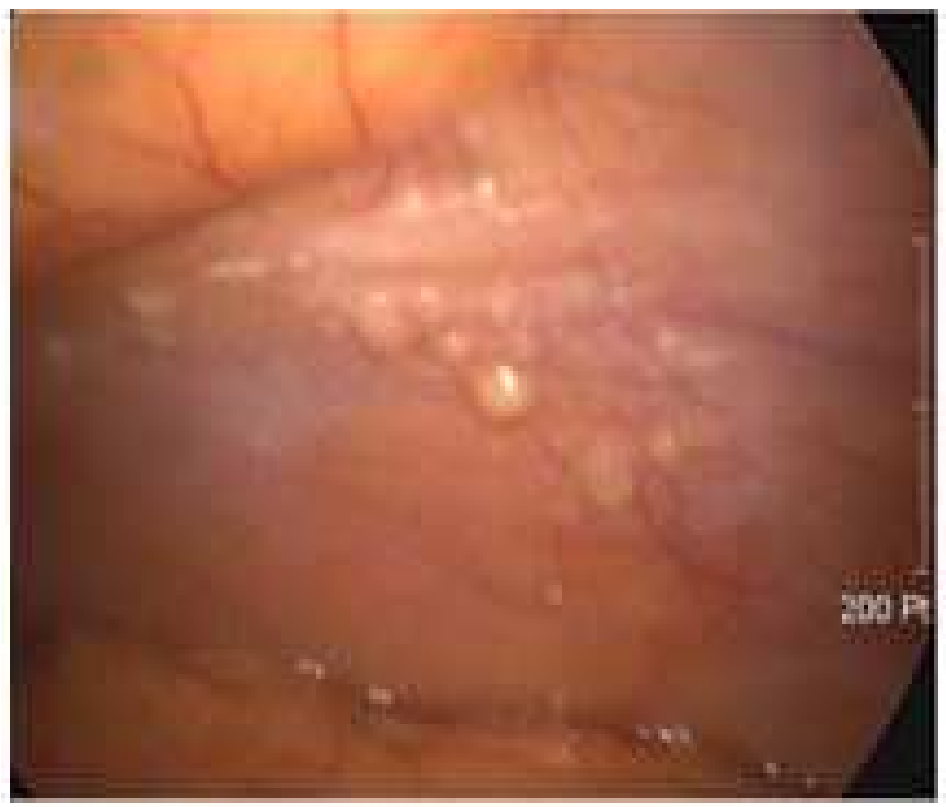

Fig. 3. Laparoscopic view of tumor whitish nodules on parietal peritoneum (courtesy of Dr. Hyuong Sun Jang and Ki Young Ru) 

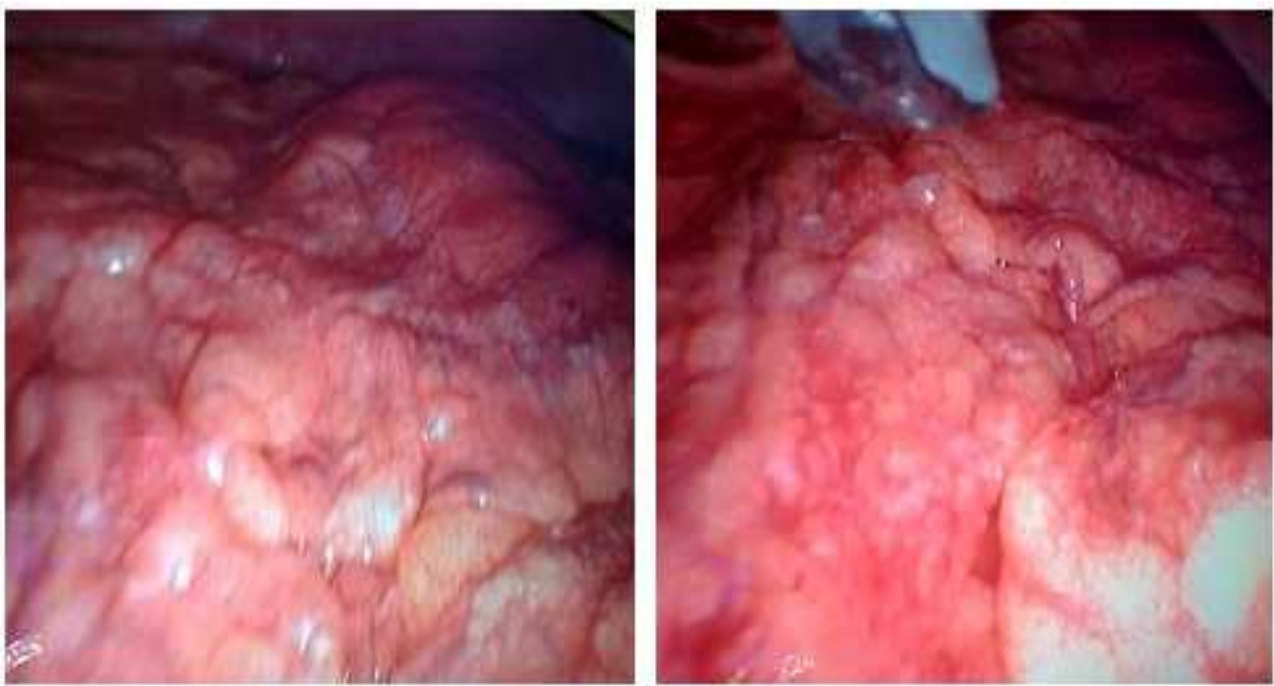

Fig. 4. Laparoscopic view of omental "caking" due to confluent nodules.

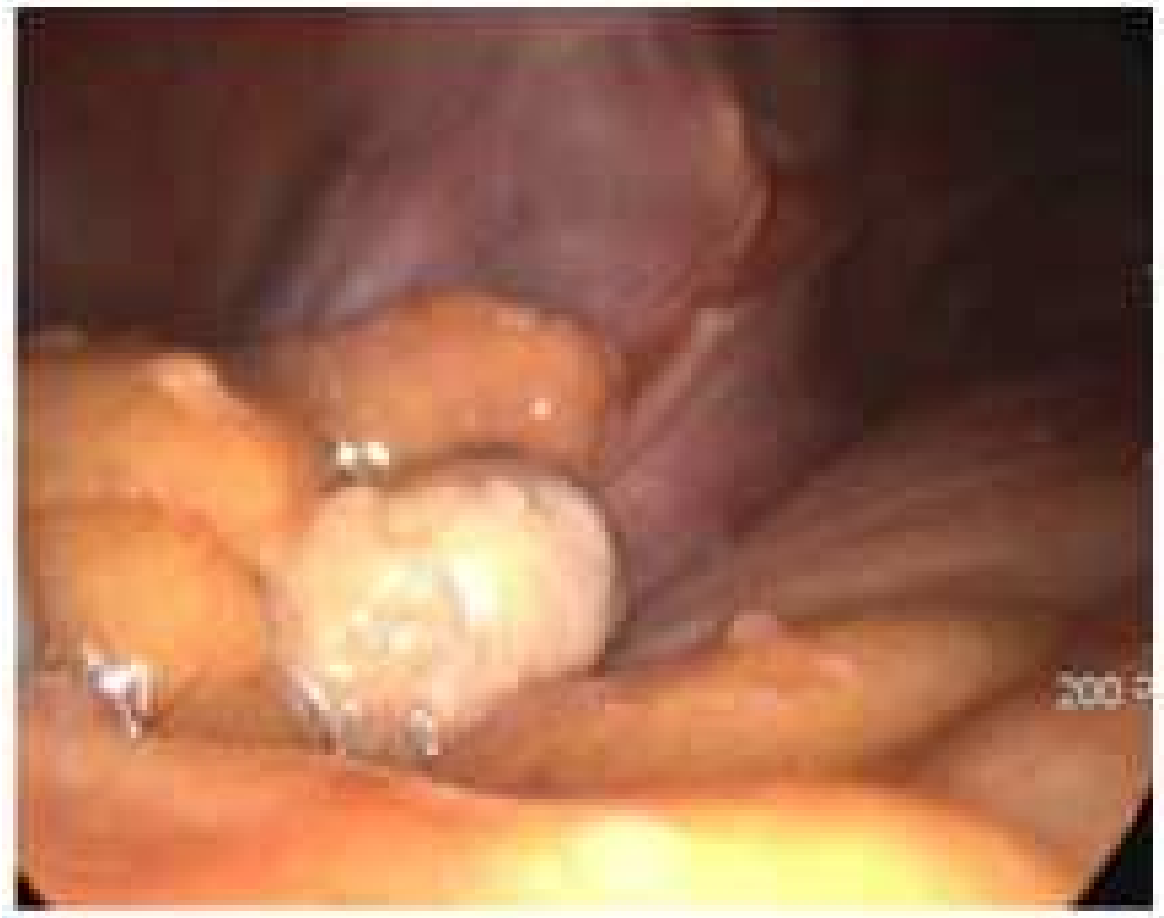

Fig. 5. Laparoscopic view of multiple nodules in the ovarian surface (courtesy of Dr. Hyuong Sun Jang and Ki Young Ru). 
b. The absence of direct or indirect signs of other abdominal neoplasms.

c. The absence of hepatic metastases or the possible presence of nodules or plaques on Glisson's capsule without parenchyma envolvement. Just in the advanced states of the disease, the tumor infiltrates the capsule of the liver with later extension within the parenchyma and retroperitoneal structures.

d. Ascites is practically constant and is variable in color from yellowish to cloudy to bloodstained. The ascitic fluid is usually serosanguinous or grossly blood-stained, but does not constitute a definitive diagnosis of peritoneal tumor.

e. Little hyperemia that extends to all the peritoneum. It serves to the gross differentiation criterion of the inflammatory form, where the parietal peritoneum is erythematous.

f. The presence of adhesions between the intestinal loops and the abdominal wall, that is typical of active tuberculosis, can in addition be seen in mesothelioma. In the case of Tuberculosis, when entering the cavity a multitude of adhesions between the different abdominal organs are present, emphasizing the hepatic adhesions ${ }^{47}$ (Figure 6).
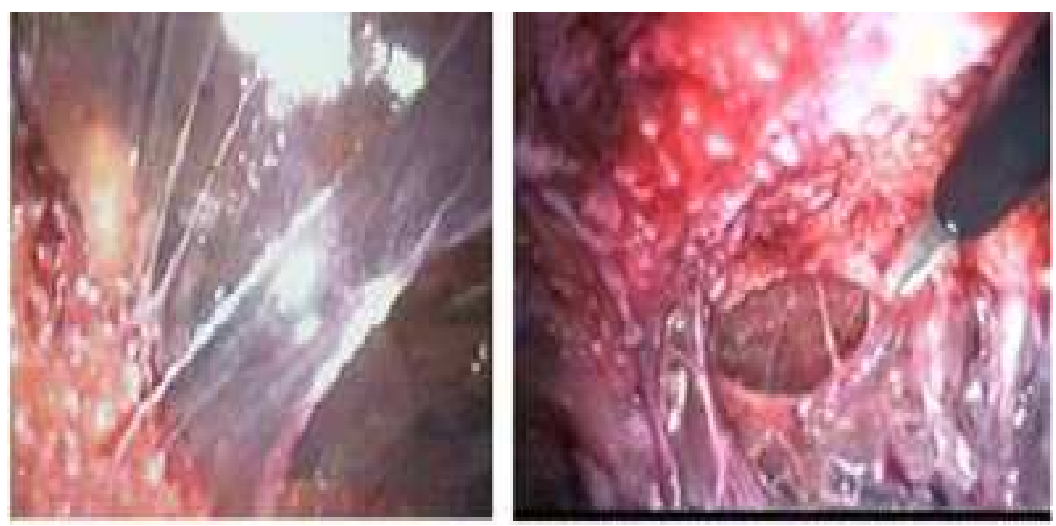

Fig. 6. Laparoscopic view of Peritoneal Tuberculosis: numerous small yellow-white nodules on the parietal peritoneum and adhesions (courtesy of Dr Suárez-Grau and Dr Morales Conde)

\subsection{Biopsy}

The laparoscopic surgery, in comparison with its diagnostic effectiveness, goes naturally considered as a whole and therefore not only with the inspection of the abdominal cavity, but with the biopsy for the histological diagnosis it is of extraordinary effectiveness ${ }^{48}$ adding diagnostic accuracy, due to the following reasons:

- It can be done on several organs: Multiple biopsies of the parietal peritoneum, diaphragm, omentum and lesion of the pelvic cavity.

- It comes often on the guide from the laparoscopic, reason why it is of particular importance when the injuries are unique. The biopsy must be taken near the edges close to the nodule and the peritoneum in order to avoid the central necrosis.

- The site of the biopsy is not forced as by the transcutaneous biopsy; it can be taken with direct vision.

- The histological fragment has the sufficient quality to assure the most precise examination (Figure 7). 

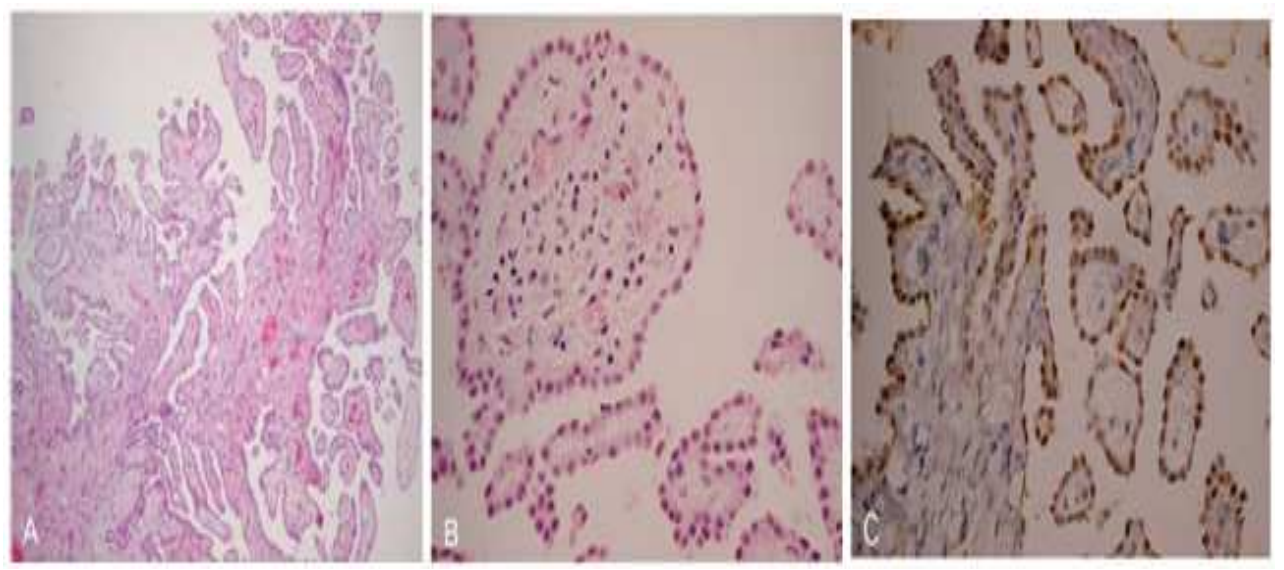

Fig. 7. Well-differentiated Papillary Mesothelioma of Peritoneum Microscopic Findings. A. Well-developed papillae lined by uniform mesothelial cells with minimal cytologic atypia. B. Neoplastic mesothelial cell shows strong positive staining for Cytokeratins. C. Inmunohistochemical staining for Calretin.

\subsection{Complications}

\subsubsection{Tear of Adhesions}

In some cases the adhesions are present, the small intestine loops tightly adherent to abdominal wall, with a careful open technique using a Hasson trocar to enter the abdominal cavity, these complications are rare. Beside, the substitution of the view field by a red veil indicates that the window of the optics has been applied on the small intestine or the adhesion; in these cases avoid to continue the movement, because it could originate a tear of the adhesions.

\subsubsection{Hemorrhage}

The observation of the biopsy site is a fundamental requirement to avoid any type of haemorrhagic complication. The laparoscopic biopsy is practically risk free, due to the use of coagulation to form a clot or by positioning fibrin dressings.

\subsubsection{Port-site metastases}

Recurrences at the insertion site of the laparoscope or other instruments for malignant mesothelioma as well as WDPMP have been reported, this source of disease usually progresses fast compared to the intraabdominal component and requires extensive surgery for the local control.13,22,38,49 The aggressive nature of such recurrences is evident. According to Sugarbaker, ${ }^{27}$ any invasive procedure used to establish the diagnosis of mesothelioma, including the paracentesis, should be carried out with great precaution and they recommend that paracentesis or laparoscopic surgery should be carried out along the midline of the abdominal wall, allowing the port site and the needle tract to be excised as part of the cytoreductive surgery. 


\section{Conclusion}

Well-Differentiated Papillary Mesothelioma is an entity rarely observed and difficult to diagnose. Laparoscopy with biopsy under direct vision is an accurate and safe technique to confirm the diagnostic.

\section{Acknowledgment}

We acknowledge Fritz Dorries for his expert assistance in the preparation of the manuscript.

\section{References}

[1] Legha SS, Muggia FM.(1977). Pleural mesothelioma: clinical features and therapeutic implications. Annals of Internal Medicine, Vol.87, No.5, (November 1977), pp.613-21, ISSN 0003-4819.

[2] Asensio JA, Goldblatt P, Thomford NR.(1990). Primary malignant peritoneal mesothelioma. A report of seven cases and a review of the literature. Archives of Surgery, Vol.125, No.11, (November 1990),pp. 1477-81. ISSN 0004-0010.

[3] Reuter K, Raptopoulos V, Reale F, Krolikowski FJ, D'Orsi CJ, Graham S, Smith EH. (1983). Diagnosis of peritoneal mesothelioma: computed tomography, sonography, and fine-needle aspiration biopsy. American Journal of Roentgenology, Vol.140, No.6, (June 1983),pp.1189-94. ISSN 1546-3141.

[4] Bridda A, Padoan I, Mencarelli R, Frego M. (2007). Peritoneal Mesothelioma: A Review. Medscape General Medicine, Vol.9, No.2, (May 2007),pp.32. ISSN 1531-0132.

[5] Kass EM.(1996). Pathology of Peritoneal Mesothelioma. Pathology of Peritoneal Mesothelioma. Cancer Treatment and Research, Vol.81, pp.213-225. ISSN 0927-3042.

[6] Butnor K, Sporn TA, Hammar SP, Roggli VL.(2001). Well-Differentiated Papillary Mesothelioma. The American Journal of Surgical Pathology, Vol.25, No.10, (October 2001), pp.1304-1309. ISSN 1532-0979.

[7] Daya D, McCaughey WT. (1991). Pathology of the peritoneum: A review of select topics. Seminars in Diagnostic Pathology, Vol. 8, No.4, (November 1991), pp.277-89. ISSN 0740-2570.

[8] Daya D, McCaughey WT. (1990). Well-differentiated papillary mesothelioma of the peritoneum: a clinicopathologic study of 22 cases. Cancer, Vol.65, No.2, (January 1990), pp.292-296. ISSN 1097-0142.

[9] Goldblum J, Hart WR. (1995). Localized and Diffuse Mesothelioma of the genital tract and peritoneum in women: a clinicopathologic study of nineteen true mesothelial neoplasm other than adenomatoid tumors, multicystic mesothelioma and localized fibrous tumors. The American Journal of Surgical, Vol.19, No.10, (October 1995), pp. 1124-37. ISSN 1532-0979

[10] Hoekman K, Tognon G, Risse EKJ. (1996). Well-differentiated papillary mesothelioma of the peritoneum a separate entity. European Journal of Cancer, Vol.32A, No.2, (February 1996), pp.355-8. ISSN 1879-0852

[11] McCoughey WTE. (1985). Papillary Peritoneal Neoplasm in Females. Pathology Annual, Vol.20, (1985), pp.387-404. ISSN 0079-0184 
[12] Roggli VL, Kolbeck J, SanFilippo F. (1987). Pathology of Human Mesothelioma: etiologic and diagnostic considerations. Pathology Annual, Vol.22, (1987), pp.91-131. ISSN 0079-0184

[13] Min-Jung KI, Moon EJ, Park YJ, Roh JW, Park YS, Park SY, Kim HS, Sim JS, Park SY. (2001). A Case of well-differentiated Papillary Mesothelioma developing malignant mesothelioma with seeding mass on the trocar insertion site of diagnostic laparoscopy and malignant change. Cancer Research and Treatment, Vol 33, No.4, (January 2001), pp. 357-361. ISSN 2005-9256.

[14] Foyle A, Al-Jabi M, McCaughey WT. (1985). Papillary Peritoneal Tumors in Women. The American Journal of Surgical Pathology, Vol.5, No.3, (April 1985), pp.241-9. ISSN 1532-0979

[15] Goepel JR. Benign Papillary Mesothelioma of Peritoneum: A Histological, Histochemical and Ultrastructural Study of Six Cases. Histopathology, Vol.5, No.1, (January 1981), pp.21-30. ISSN 1365-2559

[16] Hollinger P, Gaeng D. (1997). Simultaneous bilateral spontaneous pneumothorax in a patients with peritoneal and pleural papillary mesothelioma. Respiration; International Review of Thoracic Diseases, Vol.64, No.3, (1997), pp.233-5. ISSN 14230356

[17] Hejmadi R, Ganesan R, Kamal NG. (2003). Malignant transformation of a welldifferentiated peritoneal papillary mesothelioma. Acta Cytologica, Vol.47,No.3,(May-June 2003).pp.517-8. ISSN 1938-2650

[18] Burrig KF, Pfitzer P, Hort W.(1990). Well-differentiated papillary mesothelioma. Report of two cases and review of literature. Virchows Archiv. A, Pathological anatomy and histopathology. Vol. 417, No.5, (1990), pp. 443-7, ISSN 0174-7398

[19] Lovell FA, Cranston PE. (1990). Well-Differentiated Papillary Mesothelioma of the Peritoneum. American Journal of Roentgenology, Vol.155, No.6, (December 1990), pp.1245-1246. ISSN 1546-3141

[20] Meister T, Birkfellner T, Poremba C, Becker JC, Menzel J, Domschke W, Lerch MM. (2003). Papillary Mesothelioma of the Peritoneum in the absence of asbestos exposure. Zeitschrift für Gastroenterologie, Vol.41, No.4, (April 2003), pp.329-32. ISSN 1439-7803

[21] Porpora MG, Bracato V, D`Elia C, Natilli M, Alo PL, Cosmi EV. (2002). Laparoscopic Diagnosis and Treatment of Well Differentiated Papillary mesothelioma of the Peritoneum. The Journal of the American Association of Gynecologic Laparoscopists, Vol.9, No. 3, (August 2002), pp.384-8. ISSN 1074-3804

[22] Averbach AM, Sugarbaker PM. (1996). Peritoneal Mesothelioma Treatment approach based on natural history. Cancer Treatment and Research, Vol.81, (1996), pp.193-211. ISSN 0927-3042

[23] Jang HS, Kim SR, Ryu KYU, Kim JW, Cho SH. (2009). A Laparoscopy Diagnosis of WellDifferentiated Papillary Mesothelioma of the Peritoneum in a women with ascitis: A case report. Journal Of Women's Medicine, Vol.2, No.2, (2009), pp.81-84. ISSN 22336222

[24] Sugarbaker PH, Acherman YIZ, González-Moreno S, Ortega-Pérez G, Stuart OA, Marchettini P, You Di. (2002). Diagnosis and Treatment of Peritoneal Mesothelioma: The Washington Cancer Institute Experience. Seminars in Oncology, Vol 29, No.1, (February 2002), pp.51-61. ISSN 1532-8708 
[25] Welch LS, Acherman YIZ, Haile E, Sokas Rk, Sugarbaker PH. (2005). Asbestos and Peritoenal Mesothelioma among college-educated men. International Journal of Occupational and Environmental Health, Vol.11, No.3, (July-September 2005) pp.254258. ISSN 1077-3525

[26] Acherman YIZ, Welch LS, Branley CM, Sugarbaker PH. (2003). Clinical presentation of peritoneal mesothelioma. Tumori, Vol.89, No.3, (May-Jun 2003), pp.269-273, ISSN 2038-2529

[27] Tanimu S, Centeno B, Klapman J. (2009). Diagnosis of Malignant Peritoneal Mesothelioma by Rectal Endoscopic Ultrasound with Fine-needle Aspiration. Gastroenterology \& Hepatology, Vol.5, No.2, (February 2009), pp.142-145. ISSN 14401746.

[28] Gong Y, Ren R, Ordóñez NG, Sun X, Sneige N. (2005). Fine needle aspirations cytology of Well-Differentiated Papillary Mesothelioma: A case Report. Acta Cytologica, Vol.49, No.5, (September-October 2005), pp.537-42. ISSN 1938-2650

[29] Aramburu JA, Nájera L, Rodríguez JM.(2005) Hallazgos citomorfológicos del mesotelioma papilar bien diferenciado. A propósito de un caso y revisión de la Literatura. Revista Española de Patología, Vol. 38, No.3, (2005), pp.172-175. ISSN 1988561X

[30] Hassan R, Alexander R, Antman K, Boffetta P, Churg A, Coit D, Hausner P, Kennedy R, Kindler H, Metintas M, Mutti L, Onda M, Pass H, Premkumar A, Roggli V, Sterman D, Sugarbaker P, Taub R, Verschraegen C. (2006). Current treatment options and biology of peritoneal mesothelioma: meeting summary of the first NIH peritoneal mesothelioma conference. Annals of Oncology, Vol.17, (April 2006),pp. 1615-1619. ISSN 1569-8041

[31] Eslami B, Lutcher CL. (1974). Ante Morten Diagnosis in Two Cases of Malignant Peritoneal mesothelioma. The American Journal of the Medical Sciences, Vol.267, No.2, (February 1974), pp. 117-121. ISSN 1538-2990

[32] McCallum RW, Maceri DR, Jensen D, Berci J. (1979). Laparoscopic Diagnosis of peritoneal Mesothelioma. Report of a Case and Review of the Diagnostic Approach. Digestive Disease and Sciences, Vol. 24, No.2, (February 1979), pp. 170-174. ISSN 15732568

[33] Milingos S, Protopapas A, Papadimitriou C, Rodolakis A, Kallipolitis G, Skartados N, Markaki S, Dimopoulous MA, Antsaklis A. (2007). Laparoscopy in the evaluation of women with unexplained ascites: an invaluable diagnostic tool. Journal of Minimally Invasive Gynecology, Vol. 14, No.1, (Jan-Feb 2007), pp. 43-48. ISSN 1553-4669

[34] Van de Walle P, Blomne Y, Van Outryve L. (2004). Laparoscopy and primary diffuse malignant peritoneal mesothelioma: a diagnostics challenge. Acta Chirurgica Belgica, Vol. 104, No.1, (Feb 2004), pp. 114-7. ISSN 0001-5458

[35] Stamat JC, Chekan EG, Ali A, Ko A, Sporn TA, Eubanks WS. (1999). Laparoscopy and mesothelioma. Journal of laparoendoscopic $\mathcal{E}$ advanced surgical techniques. Part A, Vol. 9, No.5, (October 1999),pp. 443-7. ISSN 1557-9034

[36] Estrada-Saiz RV, Loscos JM, García-Paredes J, Del Pozo A, Estrada V. (1995). The role of laparoscopy in the diagnosis of primary peritonealmesothelioma. Revista Española de Enfermedades Digestivas, Vol.87, No.5, (May 1995), pp.403-6. ISSN 1130-0108 
[37] Chu CM, Lin SM, Peng SM, Wu CS, Liaw YF. (1994). The role of laparoscopy in the evaluation of ascites of unknown origin. Gastrointestinal Endoscopy, Vol. 40, No.3, (May 1994), pp.285-9. ISSN 1097-6779

[38] Muensterer OJ, Averbach AM, Jacquet P, Otero SE, Sugarbaker PH. (1997). Malignant peritoneal mesothelioma. Case-report demonstrating pitfalls of diagnostic laparoscopy. International Surgery,Vol.82, No.3, (Jul-Sep 1997), pp.240-3. ISSN 00208868

[39] Yoon YJ, Ahn SH, Park JY, Chon CY, Kim Do Y, Park YN, Han KH. (2007). What is the role of diagnostic laparoscopy in a gastroenterology Unit? Journal of Gastroenterology, Vol.33, No.5, (November 2007), pp.633-638, ISSN 1435-5922

[40] Piccigallo E, Jeffers LJ, Reddy Kr, Caldironi MW, Parenti A, Schiff ER. (1988). Malignant Peritoneal Mesothelioma. A clinical and Laparoscopic Study of ten cases. Digestive Diseases And Sciences, Vol. 33, No.5, (May 1988), pp. 633-638, ISSN 1573-2568

[41] Aponte-Rueda ME, Nieves M. (2009). Mesotelioma Papilar Bien Diferenciado. Revista Venezolana de Oncología, Vol.21, No.4, (2009), pp.229-236, ISSN 0798-0582

[42] Conlon K, Rusch V, Gillern S.(1996). Laparoscopy: An Important Tool in the Staging of Malignant Pleural Mesothelioma. Annals of Surgical Oncology, Vol.3, No.5, (September 1996), pp.489-494, ISSN 1534-4681

[43] Shukunami K, Hirabuki S, Kaneshima M, Kamitani N, Kotsuji F.(2000). WellDifferentiated Papillary Mesothelioma involving the peritoneal and pleural cavities: successful treatment by local and systemic administration of carboplatin. Tumori, Vol.86, No.5, (September-Octuber 2000) pp.419-2. ISSN 2038-2529

[44] Nezhat FR, DeNoble Shaghayegh M, Brown DN, Shamshirsaz Amir, Hoehn D. (2010). Laparoscopic Management of Peritoneal Mesohelioma associated with pelvic endometriosis. The Journal of Minimally Invasive Gynecology, Vol 17. No.5, (September-October 2010), pp.646-650, ISSN 1553-4669

[45] Hasson HM. (1971). A modified instrument and method for laparoscopy. American Journal of Obstetrics and Gynecology, Vol.110, No.6, (July 1971), pp.886-7. ISSN 10976868

[46] Henning H, Lightdale CJ, Look D. (1994). Color Atlas of Diagnostic Laparoscopy, G. Thieme Verlag, ISBN 9780865772892, Stuttgart, Germany.

[47] Suárez-Grau JM, Rubio C, García JL, Martín JA, Socas M, Álamo JM, López F, Cadet H, Bustos M, Tutosaus JD, Morales S. (2007). Presentación atípica de tuberculosis peritoneal. Caso clínico diagnosticado por laparoscopia. Revista Española de Enfermedades Digestivas, Vol. 99, No.12, (2007), pp.725-728, ISSN 1130-0108.

[48] Roskos M, Popp MB. (1999). Laparoscopic Diagnosis and Management of Malignant Ascites. Surgical Laparoscopy, Endoscopy \& Percutaneous Techniques, Vol. 9, No.5, (October 1999), pp.365-368, ISSN 1534-4908

[49] Carmignani CP, Sugarbaker PH. (2004). Regional lymph node metastases from port site implants after laparoscopic surgery. Surgical Endoscopy, Vol. 18, No.12, (December 2004), pp.1818, ISSN 1432-2218 


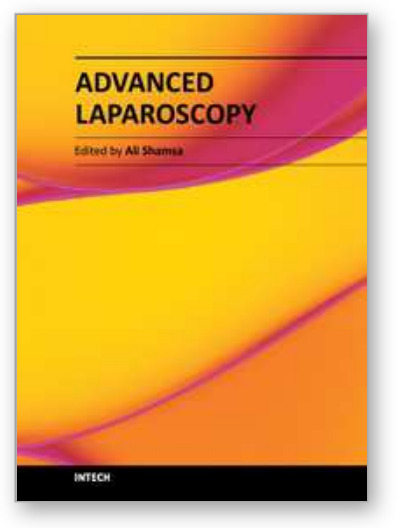

\author{
Advanced Laparoscopy \\ Edited by Prof. Ali Shamsa
}

ISBN 978-953-307-674-4

Hard cover, 190 pages

Publisher InTech

Published online 30, September, 2011

Published in print edition September, 2011

The present book, published by InTech, has been written by a number of highly outstanding authors from all over the world. Every author provides information concerning treatment of different diseases based on his or her knowledge, experience and skills. The chapters are very useful and innovative. This book is not merely devoted to urology sciences. There are also clear results and conclusions on the treatment of many diseases, for example well-differentiated papillary mesothelioma. We should not forget nor neglect that laparoscopy is in use more extensively than before, and in the future new subjects such as use of laparascopy in treatment of kidney cysts, simple nephrectomy, pyeloplasty, donor nephrectomy and even robotic laparoscopy will be researched further.

\title{
How to reference
}

In order to correctly reference this scholarly work, feel free to copy and paste the following:

Maria Eugenia Aponte-Rueda, Ramón Saade-Cárdenas and Salvador Navarrete-Aulestia (2011). Laparoscopy and Well-Differentiated Papillary Mesothelioma of the Peritoneum, Advanced Laparoscopy, Prof. Ali Shamsa (Ed.), ISBN: 978-953-307-674-4, InTech, Available from: http://www.intechopen.com/books/advancedlaparoscopy/laparoscopy-and-well-differentiated-papillary-mesothelioma-of-the-peritoneum

\section{INTECH}

open science | open minds

\section{InTech Europe}

University Campus STeP Ri

Slavka Krautzeka 83/A

51000 Rijeka, Croatia

Phone: +385 (51) 770447

Fax: +385 (51) 686166

www.intechopen.com

\section{InTech China}

Unit 405, Office Block, Hotel Equatorial Shanghai

No.65, Yan An Road (West), Shanghai, 200040, China

中国上海市延安西路65号上海国际贵都大饭店办公楼 405 单元

Phone: +86-21-62489820

Fax: +86-21-62489821 
(C) 2011 The Author(s). Licensee IntechOpen. This chapter is distributed under the terms of the Creative Commons Attribution-NonCommercialShareAlike-3.0 License, which permits use, distribution and reproduction for non-commercial purposes, provided the original is properly cited and derivative works building on this content are distributed under the same license. 